\title{
Asthma treatment in children: A guide to screening for and management of hypothalamic-pituitary-adrenal axis suppression
}

\author{
E W Zöllner, PhD, MMed, MB ChB, DCH, DTM\&H, DPH \\ Endocrine Unit, Department of Paediatrics and Child Health, Faculty of Medicine and Health Sciences, Stellenbosch University, Cape Town, \\ South Africa
}

Corresponding author: EW Zöllner (zollner@sun.ac.za)

\begin{abstract}
A recently published approach to paediatric asthma management neither recommended screening for nor suggested any management of hypothalamic-pituitary-adrenal axis suppression in asthmatic children treated with corticosteroids. The existing literature on this topic was therefore reviewed and the quality of the evidence assessed. Recommendations for diagnosis, screening and management are made utilising the Grading of Recommendations Assessment, Development and Evaluation (GRADE) approach.
\end{abstract}

S Afr Med J 2019;109(5):306-309. DOI:10.7196/SAMJ.2019.v109i5.13932

Inhaled corticosteroids (ICS) and to a lesser extent nasal steroids (NS) have undoubtedly revolutionised asthma therapy and improved quality of life in a cost-effective way. However, current evidence suggests that every asthmatic child on corticosteroids is at risk of hypothalamic-pituitary-adrenal axis suppression (HPAS). As most patients with this complication are asymptomatic, those most at risk should be screened. If screening is inconclusive, adrenal function testing should be performed. On the basis of its outcome the most appropriate management should be determined.

In a recently published approach to paediatric asthma management, ${ }^{[1]}$ treatment modifications included a 3-day course of rescue oral corticosteroids, intermittent use of ICS, a single ICS dose in the morning if possible, and a more prominent role for non-steroid controller medication. All these measures will protect the hypothalamic-pituitary-adrenal axis from suppression. However, the article neither recommended screening for nor suggested any management of HPAS.

Whenever exogenous corticosteroids are prescribed, endogenous cortisol production is reduced. This 'systemic effect' is determined by the dose, delivery device, technique, adherence, body surface area, body mass index (BMI) and duration of therapy, the number of corticosteroids being used and their pharmacokinetic characteristics, and genetic and epigenetic factors. ${ }^{[2-4]}$ Age and gender are not predictors, unless the dose has not been adjusted to body surface area. ${ }^{[5]}$ At supraphysiological ICS doses, $50 \%$ of children can be expected to develop HPAS, ${ }^{[2]}$ while at physiological doses (i.e. a cortisol production rate of $\left.3.0-10.6 \mathrm{mg} / \mathrm{m}^{2}\right)^{[6]}$ dose and effect have an inverse relationship. ${ }^{[2]}$ Hypocortisolaemia has even been described at physiological doses. ${ }^{[2,7,8]}$ HPAS is usually seen in all children after 6 - 42 months of ICS therapy, ${ }^{[3]}$ but has been observed as early as 2 months (EWZ, unpublished data, 2011). Under basal conditions no untoward effects will be apparent, because the decreased production of cortisol is balanced by the supply of exogenous corticosteroids. In the long term, the adrenal glands may atrophy. During a stressful event such as an infection, injury, burn or surgical operation, or even an asthma exacerbation, demand for cortisol may outstrip its exogenous supply. The stress can precipitate an adrenal crisis, which may lead to death. When CYP3A4 enzyme inhibitors (antiretrovirals, antifungals, calciumchannel blockers, certain antibiotics and antidepressants) ${ }^{[9]}$ are coadministered, metabolism of corticosteroids is reduced, resulting in HPAS or Cushing's syndrome. ${ }^{[10]}$

In order to make recommendations for diagnosis, screening and management of HPAS in asthmatic children, I have reviewed the existing literature and presented the quality of the evidence assessed in three tables. The Grading of Recommendations Assessment, Development and Evaluation (GRADE) approach was used. It classifies the quality of the evidence as high, moderate, low or very low, with the recommendations being either strong or weak. ${ }^{[1]}$ Management suggestions that could not be substantiated by evidence are labelled 'ungraded best practice. ${ }^{[12]}$

\section{Diagnosis of HPAS}

HPAS presents as a spectrum (Table 1). Adrenal crisis is the most devastating presentation, but occurs rarely. ${ }^{[13]}$ Chronic adrenal insufficiency (CAI) is frequently overlooked owing to its nonspecific clinical features.$^{[7]}$ For these reasons it is essential to diagnose HPAS in its subclinical state. The overnight metyrapone test should be used to make the definitive diagnosis of HPAS. ${ }^{[14]}$ If metyrapone is not available, the $0.5 \mu \mathrm{g} / 1.73 \mathrm{~m}^{2}$ adrenocorticotrophic hormone (ACTH) stimulation test is a good second choice, provided serum cortisol levels are measured at 10,15, 20, 25, 30 and 35 minutes. ${ }^{[15]}$ Clinicians utilising the ACTH stimulation test need to be aware of several pitfalls. ${ }^{[16]}$ Interpretation of results is assay specific. In 2015, Roche launched its Elecsys Cortisol II assay. It is more specific than the older cortisol assay and shows lower cross-reactivity, generating cortisol levels that are $\sim 30 \%$ lower. ${ }^{[17]}$ The pass criterion for the test therefore has to be down-adjusted to $350 \mathrm{nmol} / \mathrm{L}$ (from $500 \mathrm{nmol} / \mathrm{L}$ ). No adjustments need to be made for levels $<250 \mathrm{nmol} / \mathrm{L}$, because the old and new assays correlate well at lower levels.

\section{Screening for HPAS}

Screening for HPAS (Table 2) is problematic, because no useful screening test has been identified so far. ${ }^{[18]}$ Measurement of early- 
Table 1. Diagnostic features of HPAS

\begin{tabular}{|c|c|c|c|}
\hline Presentation & Clinical features & Serum cortisol & $\begin{array}{l}\text { Strength of recomm- } \\
\text { endation/level of evidence }\end{array}$ \\
\hline \multicolumn{4}{|l|}{ Clinical } \\
\hline Adrenal crisis & $\begin{array}{l}\text { Hypoglycaemia }^{*} \text { - depressed level } \\
\text { of consciousness/coma, convulsions; } \\
\text { nausea (hypotension, syncope, severe } \\
\text { weakness, abdominal pain, vomiting, } \\
\text { backache, hyponatraemia, hyperkalaemia, } \\
\text { hypercalcaemia) }\end{array}$ & Usually $<138 \mathrm{nmol} / \mathrm{L}$ & Strong/moderate \\
\hline CAI & $\begin{array}{l}\text { Lassitude, weakness, dizziness, nausea, } \\
\text { headache, poor growth, weight loss, } \\
\text { (orthostatic hypotension) }^{\dagger}\end{array}$ & $<138 \mathrm{nmol} / \mathrm{L}$ at $08 \mathrm{~h} 00-10 \mathrm{~h} 00$ & Weak/very low \\
\hline \multicolumn{4}{|l|}{ Subclinical } \\
\hline Hypocortisolaemia & Inability to respond appropriately to stress & $<138 \mathrm{nmol} / \mathrm{L}$ at $08 \mathrm{~h} 00-10 \mathrm{~h} 00$ & Weak/low \\
\hline Failed adrenal function test ${ }^{*}$ & Inability to respond appropriately to stress & $138-350 \mathrm{nmol} / \mathrm{L}^{\S}$ at $08 \mathrm{~h} 00-10 \mathrm{~h} 00$ & Strong/moderate \\
\hline
\end{tabular}

Table 2. Screening recommendations for subclinical HPAS

\begin{tabular}{|c|c|c|}
\hline & & $\begin{array}{l}\text { Strength of recommendation/level of } \\
\text { evidence }\end{array}$ \\
\hline \multirow[t]{13}{*}{ Patients at highest risk } & A. On a supraphysiological total steroid dose (ICS + NS), & Strong/moderate \\
\hline & i.e. $>10.6 \mathrm{mg} \mathrm{HC}$ equivalent $/ \mathrm{m}^{2} / \mathrm{d}$ ( $>$ BUD $848 \mu \mathrm{g} / \mathrm{m}^{2} / \mathrm{d}$ or & \\
\hline & $>\mathrm{FP} 424 \mu \mathrm{g} / \mathrm{m}^{2} / \mathrm{d}$ given by MDI + spacer) & \\
\hline & B. On a physiological total steroid dose $(\leq 10.6 \mathrm{mg} \mathrm{HC}$ & \\
\hline & equivalent $/ \mathrm{m}^{2} / \mathrm{d}$ ) & \\
\hline & On multiple steroids & \\
\hline & ICS + prednisone: daily, alternate-day or recurrent & Strong/low \\
\hline & 5 -day courses $<10$ days apart & \\
\hline & $\mathrm{ICS}+\mathrm{NS}$ & Strong/moderate \\
\hline & ICS + topical potent steroids ${ }^{*}$ & Strong/low \\
\hline & Adherent to ICS + NS therapy & Strong/high \\
\hline & BMI $z$-score $<0^{\dagger}$ & Strong/moderate \\
\hline & On an enzyme inhibitor & Strong/varies with inhibitor \\
\hline \multirow[t]{4}{*}{ Screening test interpretation } & Serum cortisol at $08 \mathrm{~h} 00-10 \mathrm{~h} 00$ & \\
\hline & $<138 \mathrm{nmol} / \mathrm{L}$ : hypocortisolaemia & Weak/low \\
\hline & $>350 \mathrm{nmol} / \mathrm{L}^{\ddagger}$ : normal axis & Weak/low \\
\hline & $\begin{array}{l}138-350 \mathrm{nmol} / \mathrm{L}: \text { refer for metyrapone or } \\
0.5 \mu \mathrm{g} / 1.73 \mathrm{~m}^{2} \text { ACTH stimulation test }\end{array}$ & Strong/moderate \\
\hline Screening frequency & $\begin{array}{l}\text { If serum cortisol > } 350 \mathrm{nmol} / \mathrm{L} \text {, screen 6-monthly if } \\
\text { steroid dose not reduced }\end{array}$ & Ungraded best practice \\
\hline
\end{tabular}

morning salivary cortisone has been suggested, ${ }^{[19]}$ but its routine use is premature because it has not been evaluated against a gold-standard adrenal function test. Its low positive predictive value would also argue against its use. Endocrinologists diagnose adrenal insufficiency when the $08 \mathrm{~h} 00-10 \mathrm{~h} 00$ serum cortisol level is $<138 \mathrm{mmol} / \mathrm{L}$, ${ }^{[12,20,21]}$ while a serum cortisol level of $>350 \mathrm{nmol} / \mathrm{L}$ (as measured with the Elecsys Cortisol II assay) virtually excludes HPAS. ${ }^{[21]}$ A 06h00 - 08h00 serum cortisol level of $<83 \mathrm{nmol} / \mathrm{L}$ to suggest HPAS would be ideal, ${ }^{[2]}$ but may be impractical. There is no scientific basis for labelling a level $>276 \mathrm{nmol} / \mathrm{L}$ as safe. ${ }^{[22]}$ Given the poor performance of the serum cortisol screen, only patients at high risk should be screened. If the results are inconclusive, the patient should be referred to an endocrinologist for definitive testing.

In order to identify patients at high risk, meticulous attention should be paid to an individual asthma patient's treatment, the corresponding doses and calculation of the total steroid dose, relating this to body surface area. In addition, cognisance needs to be taken of the child's BMI, adherence to therapy and the ICS route of administration, as lung deposition, and hence dose, varies between devices. ${ }^{[1,3]}$ 


\begin{tabular}{|c|c|c|}
\hline & Management & $\begin{array}{l}\text { Strength of recommendation/ } \\
\text { level of evidence }\end{array}$ \\
\hline \multicolumn{3}{|l|}{ Clinical HPAS } \\
\hline \multirow[t]{4}{*}{ Adrenal crisis } & HC $2 \mathrm{mg} / \mathrm{kg}\left(50-100 \mathrm{mg} / \mathrm{m}^{2}\right)$ IV bolus, followed by & Strong/moderate \\
\hline & HC $2 \mathrm{mg} / \mathrm{kg} / \mathrm{d}\left(50-100 \mathrm{mg} / \mathrm{m}^{2} / \mathrm{d}\right)$ IV divided 6-hourly & \\
\hline & For hypoglycaemia: $5 \mathrm{~mL} / \mathrm{kg}$ of $10 \%$ DW IV at $3 \mathrm{~mL} / \mathrm{kg} / \mathrm{h}$ & Ungraded best practice \\
\hline & $\begin{array}{l}\text { If in shock, treat with normal saline }(0.9 \%) 20 \mathrm{~mL} / \mathrm{kg} \\
\text { (maximum } 60 \mathrm{~mL} / \mathrm{kg} \text { within } 1 \text { hour) }\end{array}$ & Ungraded best practice \\
\hline \multirow[t]{6}{*}{ CAI } & $\begin{array}{l}\mathrm{HC} \text { orally at } 8 \mathrm{mg} / \mathrm{m}^{2} / \mathrm{d}, 2 / 3 \text { given in the morning, } 1 / 32 \text { hours } \\
\text { after lunch; continued for about } 1 \text { year until axis has recovered }\end{array}$ & Weak/low \\
\hline & Modify asthma therapy by reducing steroid load on the axis & Weak/low \\
\hline & $\begin{array}{l}\text { Substitute lower ICS and NS dose by using steroid-sparing } \\
\text { medication }\end{array}$ & \\
\hline & If possible, prescribe single morning dose of ICS and NS & \\
\hline & If possible, use newer-generation $\mathrm{NS}^{*}$ & \\
\hline & $\begin{array}{l}\text { Aim for a steroid load of } \mathrm{HC} \leq 6 \mathrm{mg} / \mathrm{m}^{2} / \mathrm{d} \text { (BUD } 480 \mu \mathrm{g} / \mathrm{m}^{2} / \mathrm{d} \\
\text { or FP } 240 \mu \mathrm{g} / \mathrm{m}^{2} / \mathrm{d} \text { given by MDI + spacer) }\end{array}$ & \\
\hline \multicolumn{3}{|l|}{ Subclinical HPAS } \\
\hline Hypocortisolaemia & As for CAI & Ungraded best practice \\
\hline Failed adrenal function test & As for CAI, but omit $\mathrm{HC}$ & Ungraded best practice \\
\hline \multicolumn{3}{|l|}{ Sick-day management } \\
\hline Home management of illness with fever & & Ungraded best practice \\
\hline$>38^{\circ} \mathrm{C}$ & Double HC replacement until recovery (usually 3 days) & \\
\hline$>39^{\circ} \mathrm{C}$ & Treble HC replacement until recovery (usually 3 days) & \\
\hline $\begin{array}{l}\text { Unable to tolerate oral therapy due to } \\
\text { gastroenteritis or trauma }\end{array}$ & $\begin{array}{l}\text { HC IM/SC given at a bolus dose of } 50 \mathrm{mg} \text { for primary school } \\
\text { age children and } 100 \mathrm{mg} \text { for adolescents; continue IV/IM as for } \\
\text { adrenal crisis or switch to oral regimen depending on clinical } \\
\text { state }\end{array}$ & Ungraded best practice \\
\hline Asthma exacerbation & If prednisone is given, there is no need to give $\mathrm{HC}$ as well & Ungraded best practice \\
\hline Minor surgery & Double or treble HC dose & Ungraded best practice \\
\hline $\begin{array}{l}\text { Major surgery, trauma or disease } \\
\text { requiring intensive care }\end{array}$ & $\begin{array}{l}\text { IV HC regimen as for adrenal crisis, but tapering rapidly and } \\
\text { switching to oral regimen depending on clinical state }\end{array}$ & Ungraded best practice \\
\hline \multirow[t]{2}{*}{ Additional management } & Medic Alert bracelet & Ungraded best practice \\
\hline & Educate family & Ungraded best practice \\
\hline
\end{tabular}

\section{Management of HPAS}

Management of adrenal crisis is life-saving (Table 3). Treatment modification (besides hydrocortisone) for CAI or subclinical HPAS is essentially the same. The aim of the intervention is to keep the total steroid dose well within the lower-normal physiological range. ${ }^{[2]}$ Steroid-sparing controllers available include leukotriene receptor antagonists, long-acting beta-agonists, long-acting theophylline, tiotropium bromide, and the biological agents omalizumab, mepolizumab and dupilumab. ${ }^{[1,23]}$ Early-morning dosing of inhaled and nasal budesonide, ciclesonide, mometasone, and fluticasone propionate and furoate should be prescribed whenever symptom control allows it, thereby ensuring that the early-morning surge of ACTH is not suppressed. These four drugs have minimal systemic absorption. ${ }^{[24]}$ Should HPAS develop while on nasal beclomethasone or budesonide, nasal therapy should therefore be switched to one of the newer agents. However, beclomethasone is the preferred ICS/ NS for any child treated with an enzyme inhibitor in addition to a steroid, because it is not metabolised by cytochrome P450. ${ }^{[10]}$ Rescue oral corticosteroids should never be given for more than 3 days ${ }^{[25]}$ and should not be provided to parents to be used when necessary.
Treatment modification for HPAS has been found to be effective. ${ }^{[26]}$ Even when ICS doses are not reduced, HPAS seems to resolve in some patients. ${ }^{[2]}$ This may be due to poor adherence to therapy or an increase in airway diameter with age, resulting in better control with reduced ICS doses.

\section{Conclusions}

Any asthmatic child on corticosteroids may develop HPAS. In the absence of clinical features, serum cortisol should be used to screen those most at risk. Screening should start 6 months into therapy and include children on supraphysiological steroid doses, those on multiple steroids or enzyme inhibitors, and those adherent to therapy or who are thin. If screening is inconclusive, adrenal function testing should be performed by a paediatric endocrinologist. Appropriate management, including asthma therapy modification, should be instituted if necessary.

Declaration. None.

Acknowledgements. None.

Author contributions. Sole author. 


\section{Funding. None.}

\section{Conflicts of interest. None.}

1. Masekela R, Jeevanathrum A, Kling S, et al. Asthma treatment in children: A pragmatic approach S Afr Med J 2018;108(8):612-618. https://doi.org/10.7196/SAMJ.2018.v108i8.13164

2. Zöllner EW, Lombard CJ, Galal U, Hough FS, Irusen IM, Weinberg E. Hypothalamic-pituitaryadrenal axis suppression in asthmatic school children. Pediatrics 2012;130(6):e1512-e1519. https:// doi.org/10.1542/peds.2012-1147

3. Zöllner EW. Hypothalamic-pituitary-adrenal axis suppression in asthmatic children on inhaled corticosteroids (Part 2) - the risk as determined by gold standard adrenal function tests: A systematic review. Pediatr Allergy Immunol 2007;18(6):469-474. https://doi.org/10.1111/j.1399 3038.2007.00539.x

4. Zöllner EWA. Effects of corticosteroids on adrenal function in children with asthma. Curr Allergy Clin Immunol 2014;27(4):194-197. https://hdl.handle.net/10520/EJC162825 (accessed 6 April 2019).

5. Hawcutt DP, Jorgensen AL, Wallin N, et al. Adrenal responses to a low-dose short synacthen test in children with asthma. Clin Endocrinol 2015;82(5):648-656. https://doi.org/10.1111/cen.12655

6. Linder BL, Esteban NV, Yergey AL, et al. Cortisol production rate in childhood and adolescence. J Pediatr 1990;117(6):892-896.

7. Shenoy SD, Swift PGF, Cody D. Growth impairment and adrenal suppression on low-dose inhaled beclomethasone. J Paediatr Child Health 2006;42(3):143-144. https://doi.org/10.1111/j.1440beclomethasone.

8. Patel L, Wales JK, Kibirige MS, Massarano AA, Couriel JM, Clayton PE. Symptomatic adrenal insufficiency during inhaled corticosteroid treatment. Arch Dis Child 2001;85(4):330-334. https://doi. org $/ 10.1136 /$ adc.85.4.330

9. Horn JR, Hansten PD. Inhaled corticosteroids: Watch for drug interactions. Pharmacy Times 2004(September):66

10. Daveluy A, Raignoux C, Miromont-Salamé G, et al. Drug interactions between inhaled corticosteroids and enzymatic inhibitors. Eur J Clin Pharmacol 2009;65(April):743-745. https://doi.org/10.1007/ s00228-009-0653-4

11. Swiglo BA, Murad MH, Schünemann HJ, et al. A case for clarity, consistency, and helpfulness: Stateof-the-art clinical practice guidelines in endocrinology using the grading of recommendations, assessment, development, and evaluation system. J Clin Endocrinol Metab 2008;93(3):666-673. https:// doi.org/10.1210/jc.2007-1907

12. Bornstein SR, Allolio B, Arlt W, et al. Diagnosis and treatment of primary adrenal insufficiency: An Endocrine Society Clinical Practice Guideline. J Clin Endocrinol Metabol 2016;101(2):364-389. An Endocrine Society Clinical Practice

13. Todd GRG, Acerini CL, Ross-Russel R, Zahra S, Warner JT, McCance D. Survey of adrenal crisis Todd GRG, Acerini CL, Ross-Russel R, Zahra S, Warner JT, McCance D. Survey of adrenal crisis
associated with inhaled corticosteroids in the United Kingdom. Arch Dis Child 2002;87(6):457-461. associated with inhaled corticosteroi

14. Zöllner EW. Hypothalamic-pituitary-adrenal axis suppression in asthmatic children on inhaled corticosteroids: Part 1. Which test should be used? Pediatr Allergy Immunol 2007;18(5):401-409. https://doi.org/10.1111/j.1399-3038.2007.00540.x
15. Crowley S, Hindmarsh PC, Holownia P, et al. The use of low doses of ACTH in the investigation of adrenal function in man. J Endocrinol 1991;130(3):475-479. https://doi.org/10.1677/joe. 0.1300475 16. Zöllner EW. Letter to the Editor. Author's reply to 'Testing for hypothalamic-pituitary-adrenal axis suppression in asthmatic children. Pediatr Allergy Immunol 2008;19(5):468-470. https://doi.
a org/10.1111/j.1399-3038.2008.00725.x

17. Kline GA, Buse J, Krause RD. Clinical implications for biochemical diagnostic thresholds of adrenal sufficiency using a highly specific cortisol immunoassay. Clin Biochem 2017;50(9):475-480. https:// doi.org/10.1016/j.clinbiochem.2017.02.008

18. Zöllner EW, Lombard CJ, Galal U, Hough FS, Irusen IM, Weinberg E. Screening for hypothalamicpituitary-adrenal axis suppression in asthmatic children remains problematic: A cross-sectional study. BMJ Open 2013;3(8):e002935. https://doi.org/10.1136/bmjopen-2013-002935

19. Blair J, Lancaster G, Titman A, et al. Early morning salivary cortisol and cortisone, and adrenal responses to a simplified low-dose short Synacthen test in children with asthma. Clin Endocrinol
restir J 2014:80(3):376-383. https://doi.org/10.1111/cen.12302

20. Kazlauskaite R, Evans AT, Villabona CV; Consortium for Evaluation of Corticotropin Test in Hypothalamic-Pituitary-Adrenal Insufficiency. Corticotropin tests for hypothalamic-pituitaryadrenal insufficiency: A metaanalysis. J Clin Endocrinol Metab 2008;93(11):4245-4253. https://doi. org/10.1210/jc.2008-0710

21. Agwu JC, Spoudeas H, Hindmarsh PC, Pringle PJ, Brook CGD. Tests of adrenal insufficiency. Arch Dis Child 1999;80(4):330-333. https://doi.org/10.1136/adc.80.4.330

22. Kapadia CR, Nebesio TD, Myers SE, et al. Endocrine effects of inhaled corticosteroids in children. JAMA Pediatr 2016;170(2):163-170. https://doi.org/10.1001/jamapediatrics.2015.3526

23. Masekela R, Levin M, Jeena PM, et al. Looking beyond the magic bullet: Novel asthma drugs or education, which works better? S Afr Med J 2018;108(8):619-623; https://doi.org/10.7196/SAMJ.2018. v108i8.13163

24. Derendorf $\mathrm{H}$, Meltzer EO. Molecular and clinical pharmacology of intranasal corticosteroids: Clinical and therapeutic implications. Allergy 2008;63(10):1292-1300. https://doi.org/10.1111/j.13989995.2008.01750.x

25. Zora JA, Zimmerman D, Carey DL, O'Connell EJ, Yunginger JW. Hypothalamipituitary-adrenal suppression after short-term, high-dose glucocorticoid therapy in children with asthma. J Allergy Clin Immunol 1986;77(1):9-13. https://doi.org/10.1016/0091-6749(86)90315-5

26. Zöllner EW. Is adrenal suppression in asthmatic children reversible? A case series. S Afr Med J 2018;108(6):502-505. https://doi.org/10.7196/SAMJ.2018.v108i6.13031

27. Gangadharan A, McCoy P, Phyo A, et al. Recovery of hypothalamic-pituitary-adrenal axis suppression during treatment with inhaled corticosteroids for childhood asthma. J Asthma Allergy 2017;10:317326. https://doi.org/10.2147/JAA.S142874

Accepted 18 March 2019. 